\title{
The Optimum Plant Density for Vigorous Seed Production in Safflower
}

\author{
İsmail Özaşık ${ }^{1}$, Mehmet Demir Kaya ${ }^{2 *}$, Engin Gökhan Kulan ${ }^{3}$ \\ ${ }^{1}$ Department of Field Crops, Faculty of Agriculture, Eskişehir Osmangazi University, 26160 Eskişehir, Turkey \\ E-mail: ismail.ozasik@gmail.com,ORCID: https://orcid.org/0000-0002-2631-3414 \\ $2^{*}$ Department of Field Crops, Faculty of Agriculture, Eskişehir Osmangazi University, 26160 Eskişehir, Turkey \\ E-mail: demirkaya76@hotmail.com,ORCID: https://orcid.org/0000-0002-4681-2464 \\ ${ }^{3}$ Department of Field Crops, Faculty of Agriculture, Eskişehir Osmangazi University, 26160 Eskişehir, Turkey \\ E-mail: egk_88@hotmail.co,ORCID: https://orcid.org/0000-0002-7147-6896
}

\begin{tabular}{|c|c|}
\hline A R T I C L E I N F O & A B S T R A C T \\
\hline $\begin{array}{l}\text { Keywords: } \\
\text { Carthamus tinctorius } \mathrm{L} \text {. } \\
\text { Row spacing } \\
\text { Seeding rate } \\
\text { Yield } \\
\text { Seed vigor }\end{array}$ & $\begin{array}{l}\text { Seed viability and vigor have been influenced by several factors including soil and climatic } \\
\text { conditions, plant nutrition, fertilization, irrigation, plant population and post-harvest storages. The } \\
\text { study was conducted to determine the appropriate plant density for vigorous seed production in } \\
\text { safflower. The effects of row spacing }(14 \text { and } 28 \mathrm{~cm}) \text { and seeding rate }(40,80,120,160 \text { and } 200 \\
\left.\text { seeds } \mathrm{m}^{-2}\right) \text { on yield, yield components and seed quality of safflower were detected in the study. } \\
\text { The results showed that increased seeding rates resulted in enhanced seed yield and the highest } \\
\text { seed yield was obtained from } 14 \mathrm{~cm} \text { and } 200 \mathrm{seed}^{-2} \text { with } 3320 \mathrm{~kg} \mathrm{ha}^{-1} \text {. The row spacing and } \\
\text { seeding rate did not cause a significant difference in oil and protein contents. Laboratory } \\
\text { emergence, germination after accelerated ageing (AA) and electrical conductivity tests were } \\
\text { suitable for determining seed quality among the seed lots, while standard germination, cool and } \\
\text { cold tests were not appropriate. The highest laboratory emergence percentage and germination } \\
\text { after AA were determined in } 80 \text { seed } \mathrm{m}^{-2} \text { but field emergence percentage in } 120 \text { seed } \mathrm{m}^{-2} \text {. It was } \\
\text { concluded that the } 14 \mathrm{~cm} \text { row spacing and seeding rate of } 120 \text { seed } \mathrm{m}^{-2} \text { should be advised for high } \\
\text { yielding seed production regardless of seed vigor in safflower. }\end{array}$ \\
\hline
\end{tabular}

(c) (1) @ (9) This work is licensed under Creative Commons Attribution 4.0 International License

\section{Introduction}

Because of irregular and inadequate rainfall under rainfed conditions in arid and semiarid regions, limited crop plants are economically grown (Flagella et al., 2002; Reddy et al., 2003). One of the most important crops to be cultivated under these conditions is safflower. Due to high tolerance to drought, a reasonable seed yield without irrigation, suitable for mechanization, low labour needs and production costs, it should be placed into crop rotation systems with cool season cereals (Weiss, 2000; Bayramin and Kaya, 2009; Elfadl et al., 2009). Under these ecological conditions, determination of the optimum plant population is a crucial issue for high yielding safflower production because average productivity is relatively low due to insufficient precipitation and soil fertility.

Plant population arranged by row spacing and seeding rate may be changed considerably depending on cultivar, crop rotation, soil and climatic conditions in safflower cultivation. In California, 30 to $60 \mathrm{~cm}$ row spacing generally give higher yields than 15 to $20 \mathrm{~cm}$ spacing; however, in Nebraska, 15 to $23 \mathrm{~cm}$ row spacing consistently produces the highest yields (Mündel et al., 1994). Weiss (2000) summarized the results on seeding rate and row spacing, indicating that very high seeding rates reduce seed yields. At Williston, North Dakota, the maximum yields were recorded with seeding rate of 16.5 $\mathrm{kg} \mathrm{ha}^{-1}$, while the seed yield did not decrease at the higher seeding rates (Riveland et al., 1977). Mündel et al. (1994) and Elfadl et al. (2009) demonstrated that higher plant density resulted in lower branch and head number; consequently, the highest seed yield was obtained from the seeding rates of 22.5 to $45.0 \mathrm{~kg} \mathrm{ha}^{-1}$ on the Canadian Prairies. Also, any information about the plant density to be used for vigorous seed production in safflower is not available. As known, safflower is a highly branched plant, which is controlled by environmental conditions, plant genetic and population. It exhibits a regular flowering order that starts the head on the main stem and continues to the primary, secondary and tertiary heads (Baydar and Ulger, 1998). This flowering pattern, which can continue up to 20-40 days, results in different sized seeds in the plant, which yield a variable seed quality (Weiss, 2000; Kaya, 2014).

The objective of the study was to determine the optimum plant density for high yielding safflower cultivation and vigorous seed production under dryland conditions of Eskişehir, Turkey. 


\section{Materials and Methods}

This study was conducted at the experimental field of Eskisehir Osmangazi University in Eskişehir, Turkey. The soil type in the experimental field was clay loam, and slightly alkaline $(\mathrm{pH}=7.8)$, rich in potassium $(2150 \mathrm{~kg} \mathrm{ha}$ $\left.{ }^{1}\right)$, intermediate in phosphorus $\left(33 \mathrm{~kg} \mathrm{ha}^{-1}\right)$ and low in organic matter $(1.13 \%)$. The field trials were carried out under rain-fed conditions. The climate was characterized by hot and dry summers, cold and snowy winters. Total precipitation from sowing to harvest was $87.8 \mathrm{~mm}$, with a 25 years average of $151 \mathrm{~mm}$. Mean temperatures during the growing period were $15.7^{\circ} \mathrm{C}$.

The safflower cv. Dinçer was sown on March 21, and $30 \mathrm{~kg} \mathrm{ha}^{-1} \mathrm{~N}$ and $70 \mathrm{~kg} \mathrm{ha}^{-1} \mathrm{P}_{2} \mathrm{O}_{5}$ (DAP, Diammonium phosphate, 18-46-0) were applied before sowing according to the results of soil analysis. Pre-emergence herbicide (Linuron $450 \mathrm{~g} \mathrm{~L}^{-1}$ ) was applied to control weeds.

The field experiment was established at split plot design with four replicates and each replicate was considered as a seed lot for seed vigor tests. Two row spaces (narrow, $14 \mathrm{~cm}$ and normal, $28 \mathrm{~cm}$ ) were considered as the main plot factors and seeding rates $(40,80,120,160$ and 200 seed $\mathrm{m}^{-2}$ ) as the sub-plot factors. There were six rows with $4 \mathrm{~m}$ long per plot for both narrow and normal row spacing.

\section{Laboratory Experiments}

Seeds were harvested separately from each plot in the field experiment and were transferred to the laboratory to determine the seed vigor. Four replicates of 50 seeds from each seed lot were germinated in three rolled filter papers with $10 \mathrm{~mL}$ of distilled water. Each rolled paper was placed into a sealed plastic bag to prevent moisture loss. The seeds were allowed to germinate at $25 \pm 1^{\circ} \mathrm{C}$ in the dark for 10 days. The seeds were considered germinated when the emerging radicle was at least $2 \mathrm{~mm}$ long. The germination percentage (GP) was recorded every $24 \mathrm{~h}$ for 10 days (ISTA, 2003).

Laboratory emergence test: Four replicates of 50 seeds from each seed lot were sown at $2 \mathrm{~cm}$ depths in sand in a seedling tray $(30 \times 20 \times 7 \mathrm{~cm})$ to determine the laboratory emergence percentage (LEP). The seedlings were grown in an incubator at $25 \pm 1^{\circ} \mathrm{C}$ for 10 days. The emerged seedlings (appearance of hypocotyls at the surface) were counted at 10 days after sowing.

Field emergence percentage (FEP): It was determined by using four sets of 50 seeds from each seed lot. The seeds were sown manually in $3 \mathrm{~m}$ long plots at a depth of 2.5-3.5 $\mathrm{cm}$ at the experimental field of the Field Crop Department. The emerged seedlings with cotyledon leaves were counted 30 days after sowing.

Cool test: Four replications of 50 seeds for each seed lot were used. They were germinated in three rolled filter papers with $10 \mathrm{~mL}$ of distilled water as described by germination test. The rolled filter papers were placed in a sealed plastic bag, which were put into a germination cabin at $18^{\circ} \mathrm{C}$ for 10 days (Hampton and TeKrony, 1995). After the incubation, germination percentage was determined according to the rules of ISTA (2003).

Cold test: Four replicates of 50 seeds from each lot were placed on three layers of filter papers with $10 \mathrm{~mL}$ of distilled water. Each rolled paper was then wrapped and placed into a sealed plastic bag. They were kept in a cold chamber at $10^{\circ} \mathrm{C}$ for four days and then transferred to germinators at $25^{\circ} \mathrm{C}$ (Loeffler et al., 1985).

Accelerated ageing test (AA): Two hundred seeds were sampled from row spacing and seeding rates, distributed over an aluminium screen in germination plastic boxes $(11 \times 11 \times 3.5 \mathrm{~cm})$. The boxes were filled with $40 \mathrm{~mL}$ of distilled water and were kept in a germination chamber for 96 hours and approximately $100 \%$ relative humidity at $45^{\circ} \mathrm{C}$ (Kaya, 2014). After ageing incubation, seeds were then transferred to the germination test described by ISTA (2003).

Electrical conductivity test (EC): It was performed by using four replications of 50 weighted seeds for each lot. The seeds were placed in $350 \mathrm{~mL}$ of plastic cups containing $200 \mathrm{~mL}$ deionized water for 24 hours at $25^{\circ} \mathrm{C}$. The electrical conductivity of the soaked water was measured using a conductivity meter (Model WTW Cond 314i, Germany) after the incubation period. The results were expressed in $\mu \mathrm{S} \mathrm{cm}^{-1} \mathrm{~g}^{-1}$ to take account for the variability in the seed weight among the seed lots.

\section{Results and Discussion}

For all the yield components, seed yield, oil and protein content, the main effects with their significance levels of row spacing and seeding rate were displayed in Table 1. The row spacing significantly influenced the plant height, branch number, head number, plant weight and seed yield of safflower. They were significantly higher in row spacing of $14 \mathrm{~cm}$ than in $28 \mathrm{~cm}$. Oil and protein contents did not show any response to row spacing and seeding rate. Increased seeding rate resulted in a decrease in plant height, branch number, head number and plant weight, while seed yield was promoted. Plant height declined gradually from $69.3 \mathrm{~cm}$ in 40 seed $\mathrm{m}^{-2}$ to $60.5 \mathrm{~cm}$ in 200 seed $\mathrm{m}^{-2}$.

An increase in seeding rate caused a dramatic reduction in branch number per plant; therefore, head number per plant diminished. The highest head number was determined in $40 \mathrm{seed} \mathrm{m}^{-2}$ with 5.58 number per plant while the lowest (2.69 number plant ${ }^{-1}$ ) was in 200 seed m$^{-2}$. These results agreed with those of Umrani and Bhoi (1984) and Gonzalez et al. (1994) as they confirmed that the increasing seeding rate resulted in a significant decrease in branch and head number of safflower. Head number per plant was clearly changed depending on branch number per plant because of each branch terminating in a head (Elfadl et al., 2009; Weiss, 2000).

A remarkable decrease in plant weight was observed when the seeding rate increased. It was decreased from $194.2 \mathrm{~g} \mathrm{plant}^{-1}$ in $40 \mathrm{seed} \mathrm{\textrm {m } ^ { - 2 }}$ to $77.0 \mathrm{~g} \mathrm{plant}^{-1}$ in $200 \mathrm{seed}$ $\mathrm{m}^{-2}$. Zadeh et al. (2012) found a decreasing biological yield from $5354 \mathrm{~kg} \mathrm{ha}^{-1}$ to $3103 \mathrm{~kg} \mathrm{ha}^{-1}$ when plant population was declined. On the other hand, row spacing $\times$ seeding rate interaction showed that increased seeding rate in narrow row spacing $(14 \mathrm{~cm})$ led to enhanced seed yield; consequently, it reached the maximum level (3320 kg ha-1) in $200 \mathrm{seed} \mathrm{m}^{-2}$. The highest seed yield in row spacing of $28 \mathrm{~cm}$ was obtained from 80 seed $\mathrm{m}^{-2}$ with $2300 \mathrm{~kg} \mathrm{ha}^{-1}$ (Figure 1). Row spacing had a greater effect than the seeding rate on safflower yield. The most favorable seed yield was obtained from seeding rate of 120 seed $\mathrm{m}^{-2}$. 
Table 1 The effects of row spacing and seeding rates on seed yield and yield components of safflower

\begin{tabular}{|c|c|c|c|c|c|c|c|}
\hline Factors & $\begin{array}{c}\text { Plant } \\
\text { height } \mathrm{cm}\end{array}$ & $\begin{array}{l}\text { Branch number } \\
\text { No. } \text { plant }^{-1}\end{array}$ & $\begin{array}{l}\text { Head number } \\
\text { No. } \text { plant }^{-1}\end{array}$ & $\begin{array}{l}\text { Plant weight } \\
\text { g plant }^{-1}\end{array}$ & $\begin{array}{l}\text { Seed yield } \\
\mathrm{kg} \mathrm{ha}^{-1}\end{array}$ & $\begin{array}{c}\text { Oil content } \\
\%\end{array}$ & $\begin{array}{c}\text { Protein } \\
\text { content } \%\end{array}$ \\
\hline \multicolumn{8}{|c|}{ Row spacing } \\
\hline $14 \mathrm{~cm}$ & $66.3^{\mathrm{a}}$ & $3.23^{\mathrm{a}}$ & $4.32^{\mathrm{a}}$ & $145.5^{\mathrm{a}}$ & $3100^{\mathrm{a}}$ & 31.2 & 14.7 \\
\hline $28 \mathrm{~cm}$ & $64.0^{\mathrm{b}}$ & $2.28^{\mathrm{b}}$ & $3.37^{\mathrm{b}}$ & $94.5^{\mathrm{b}}$ & $2160^{\mathrm{b}}$ & 31.6 & 14.2 \\
\hline \multicolumn{8}{|c|}{ Seeding rate $\left(\right.$ seed $\left.\mathrm{m}^{-2}\right)$} \\
\hline 40 & $69.3^{\mathrm{a}}$ & $4.18^{\mathrm{a}}$ & $5.58^{\mathrm{a}}$ & $194.2^{\mathrm{a}}$ & $2480^{c}$ & 31.3 & 13.8 \\
\hline 80 & $68.3^{\mathrm{a}}$ & $2.99^{\mathrm{b}}$ & $4.01^{\mathrm{b}}$ & $130.6^{\mathrm{b}}$ & $2640^{\mathrm{b}}$ & 31.1 & 14.6 \\
\hline 120 & $64.5^{\mathrm{b}}$ & $2.60^{\mathrm{bc}}$ & $3.60^{\mathrm{bc}}$ & $104.6^{\mathrm{c}}$ & $2660^{\mathrm{b}}$ & 31.1 & 15.1 \\
\hline 160 & $63.3^{\mathrm{bc}}$ & $2.34^{\mathrm{c}}$ & $3.34^{\mathrm{c}}$ & $93.7^{\mathrm{c}}$ & $2610^{\mathrm{b}}$ & 31.3 & 14.6 \\
\hline 200 & $60.5^{\mathrm{c}}$ & $1.66^{\mathrm{d}}$ & $2.69^{\mathrm{d}}$ & $77.0^{\mathrm{d}}$ & $2750^{\mathrm{a}}$ & 32.4 & 14.2 \\
\hline \multicolumn{8}{|c|}{ Summary of ANOVA } \\
\hline $\mathrm{RS}(\mathrm{A})$ & $* *$ & $* *$ & $* *$ & $* *$ & $* *$ & ns & $\mathrm{ns}$ \\
\hline $\mathrm{SR}(\mathrm{B})$ & $* *$ & $* *$ & $* *$ & $* *$ & $*$ & ns & $\mathrm{ns}$ \\
\hline $\mathrm{A} \times \mathrm{B}$ & ns & ns & ns & ns & $*$ & ns & ns \\
\hline
\end{tabular}

*significant at $\mathrm{P}<0.05,{ }^{* *} \mathrm{P}<0.01$ and ns: non-significant. Different letters in the same column show significant differences at 0.05 level, RS: Row spacing (A), SR: Seeding rate (B)

Table 2 The effects of row spacing and seeding rate on germination, emergence and seed vigor of safflower

\begin{tabular}{|c|c|c|c|c|c|c|c|}
\hline Factors & $\begin{array}{c}\text { GP } \\
\%\end{array}$ & $\begin{array}{l}\text { LEP } \\
\%\end{array}$ & $\begin{array}{c}\text { FEP } \\
\%\end{array}$ & $\begin{array}{c}\text { Cool test } \\
\%\end{array}$ & $\begin{array}{c}\text { Cold test } \\
\%\end{array}$ & $\begin{array}{c}\mathrm{EC} \\
\mu \mathrm{S} \mathrm{cm} \mathrm{cm}^{-1} \mathrm{~g}^{-1}\end{array}$ & $\begin{array}{c}\mathrm{AA} \\
\%\end{array}$ \\
\hline \multicolumn{8}{|c|}{ Row spacing } \\
\hline $14 \mathrm{~cm}$ & 98.0 & $92.0^{\mathrm{a}}$ & 45.9 & 98.3 & 98.6 & 12.95 & $73.1^{\mathrm{a}}$ \\
\hline $28 \mathrm{~cm}$ & 98.5 & $89.7^{b}$ & 58.7 & 98.0 & 98.9 & 12.24 & $66.5^{b}$ \\
\hline \multicolumn{8}{|c|}{ Seeding rate $\left(\right.$ seed $\left.\mathrm{m}^{-2}\right)$} \\
\hline 40 & 97.6 & $92.3^{a}$ & $63.4^{\mathrm{a}}$ & 98.8 & 98.8 & 11.71 & 67.3 \\
\hline 80 & 98.8 & $92.8^{\mathrm{a}}$ & $59.0^{\mathrm{ab}}$ & 98.3 & 98.4 & 12.37 & 72.9 \\
\hline 120 & 98.1 & $90.3^{\mathrm{a}}$ & $63.8^{\mathrm{a}}$ & 98.1 & 98.8 & 12.75 & 69.4 \\
\hline 160 & 98.4 & $89.9^{\mathrm{a}}$ & $51.5^{\mathrm{c}}$ & 97.4 & 99.0 & 12.48 & 70.0 \\
\hline 200 & 98.3 & $89.0^{\mathrm{b}}$ & $50.5^{\mathrm{c}}$ & 98.3 & 98.9 & 13.68 & 69.3 \\
\hline \multicolumn{8}{|c|}{ Summary of ANOVA } \\
\hline $\mathrm{RS}(\mathrm{A})$ & ns & $*$ & $\mathrm{~ns}$ & ns & $\mathrm{ns}$ & $\mathrm{ns}$ & $* *$ \\
\hline $\mathrm{SR}(\mathrm{B})$ & ns & $* *$ & $* *$ & $\mathrm{~ns}$ & ns & $\mathrm{ns}$ & $\mathrm{ns}$ \\
\hline $\mathrm{A} \times \mathrm{B}$ & ns & ns & $* *$ & ns & ns & ns & $* *$ \\
\hline
\end{tabular}

*significant at $\mathrm{P}<0.05,{ }^{*} * \mathrm{P}<0.01$ and ns: non-significant. Different letters in the same column show significant differences at $\mathrm{P}<0.05$. GP: Germination percentage, LEP: Laboratory emergence test, FEP: Field emergence test, EC: Electrical conductivity test, AA: Accelerated ageing test, RS: Row spacing (A), SR: Seeding rate (B)

Table 3 Correlation coefficients between standard germination and different vigor tests

\begin{tabular}{c|lllllllll}
\hline & GP & LEP & CT & CoT & EC & AA & FEP & OC & PC \\
\hline LEP & -0.319 & - & - & - & - & - & - & - & - \\
CT & 0.089 & -0.200 & - & - & - & - & - & - & - \\
CoT & 0.004 & -0.129 & 0.072 & - & - & - & - & - & - \\
EC & -0.181 & 0.093 & -0.396 & -0.176 & - & - & - & - & - \\
AA & -0.337 & $0.653^{*}$ & -0.394 & -0.447 & 0.445 & - & - & - & - \\
FEP & 0.302 & 0.091 & 0.520 & -0.069 & $-0.616^{*}$ & -0.233 & - & - & - \\
OC & 0.264 & $-0.623^{*}$ & -0.031 & -0.173 & 0.334 & -0.293 & -0.293 & - & - \\
PC & 0.371 & 0.306 & -0.155 & -0.016 & 0.223 & 0.471 & 0.291 & -0.366 & - \\
SY & -0.292 & 0.378 & 0.210 & -0.190 & 0.478 & $0.608^{*}$ & -0.156 & -0.322 & 0.463 \\
\hline
\end{tabular}

GP: Germination percentage, LEP: Laboratory emergence, CT: Cool test, CoT: Cold test, EC: Electrical conductivity, AA: Accelerated ageing, FEP: Field emergence, OC: Oil content, PC: Protein content, SY: Seed yield

The results of this study are consistent with the observations of Mündel et al. (1994), who observed that the seeding rate between $22.5-45.0 \mathrm{~kg} \mathrm{ha}^{-1}$ should be recommended for optimum seed yield in safflower while a seeding rate of $7.5 \mathrm{~kg} \mathrm{ha}^{-1}$ was inadequate.

Among laboratory tests, a significant two-way interaction (row spacing $\times$ seeding rate) was detected $(\mathrm{P}<0.05)$ for the field emergence (FEP) and germination after the accelerated ageing test (AA) (Table 2). But germination percentage was not significantly affected by neither row spacing nor seeding rate. Generally, it was about $98.0 \%$ in all the treatments. However, the laboratory emergence percentage in row spacing of $14 \mathrm{~cm}$ was higher than that of $28 \mathrm{~cm}$, increased seeding rate led to decreasing laboratory emergence from $92.3 \%$ to $89.0 \%$.

The seeding rate did not significantly influence the field emergence percentage while the highest emergence $(63.8 \%)$ was determined at 120 seed $\mathrm{m}^{-2}$. The interaction between row spacing and seeding rate demonstrated that field emergence of the seeds from $28 \mathrm{~cm}$ was superior to 
the seeds from $28 \mathrm{~cm}$ when seeding rate was higher than 120 seed $\mathrm{m}^{-2}$ (Figure 2). Germination percentage in cool and cold tests, and electrical conductivity values was not changed significantly by row spacing and seeding rate. Germination percentage after AA showed that higher seed viability was recorded at $14 \mathrm{~cm}$ with $73.1 \%$. The interaction demonstrated that row spacing of $14 \mathrm{~cm}$ gave a better germination performance after AA than that of 28 $\mathrm{cm}$ except for 160 seed $\mathrm{m}^{-2}$ as seen in Figure 3.

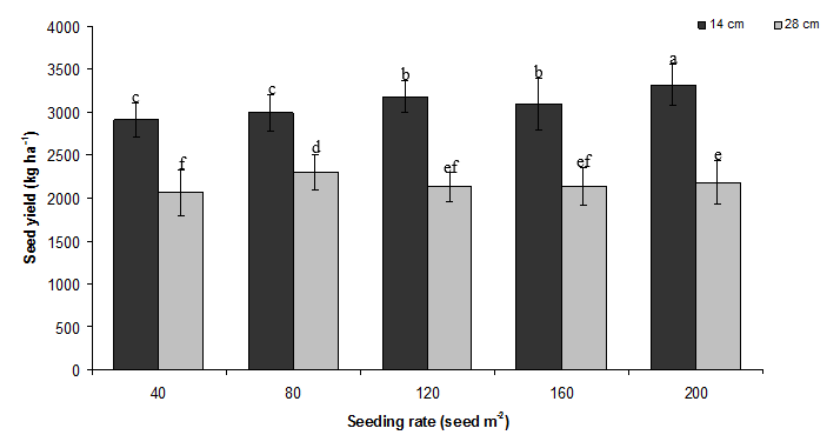

Figure 1 Changes in seed yield of safflower affected by row spacing and seeding rate

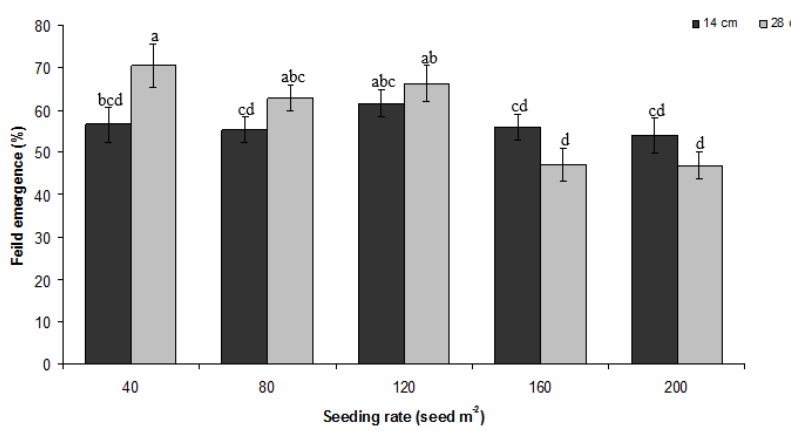

Figure 2 Changes in field emergence percentage (FEP) of safflower seeds produced by row spacing and seeding

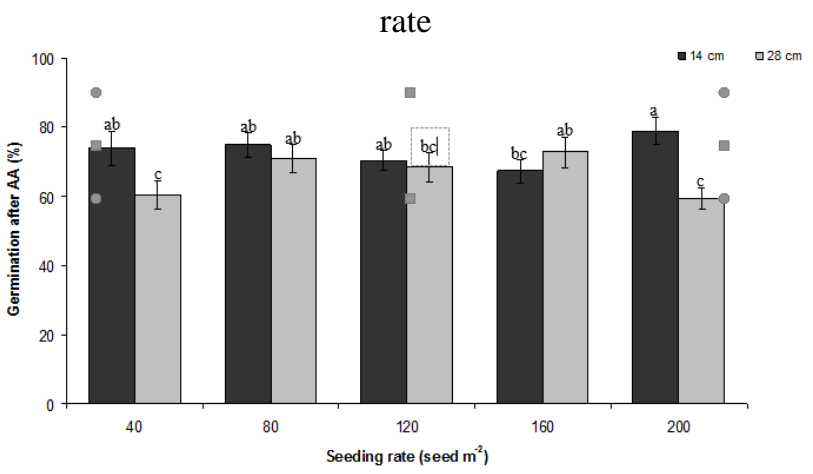

Figure 3 Changes in germination after accelerated ageing (AA) of safflower seeds produced by row spacing and seeding rate

Simple correlation coefficients calculated among the laboratory tests indicated that the laboratory emergence percentage showed a significant positive correlation with AA, but it gave a negative correlation $\left(r=-0.623^{*}\right)$ with oil content (Table 3). Similarly, field emergence percentage was negative and significantly correlated with electrical conductivity. The results of seed yield were positively correlated with AA and no significant correlation was observed with any of the vigor tests; indicating that seed vigor was enhanced by increasing seed yield in safflower. It may be argued that decreasing in branch and head number by increasing seeding rate led to produce the vigorous seeds from each head. Among the vigor tests, the highest correlation coefficient was observed between laboratory emergence and AA $\left(r=-0.653^{*}\right)$ while the best vigor test for predicting field emergence performance of safflower was the electrical conductivity test with the high correlation coefficient $\left(\mathrm{r}=-0.616^{*}\right)$. A significant relationship between the electrical conductivity and field emergence suggested that the electrical conductivity is a reliable predictor of safflower seed vigor. Kaya (2014) confirmed that it was the most efficient method to rank seed vigor in safflower as indicated by Atak et al. (2002) in pea, Vieira et al. (1999) in soybean, Coimbra et al. (2009) in sweet corn.

In conclusion, we demonstrated here the first report on plant density to be used in safflower for vigorous seed production. Seeding rate is a very important to achieve optimum plant density, higher seed yield and vigorous seed production in safflower cultivation. To avoid excessive seed usage, growers tend to sow only 40 seed $\mathrm{m}^{-2}$ of seeds. Our findings revealed that the best row spacing for high yielding and vigorous seed production was $14 \mathrm{~cm}$. Although higher seed yield was obtained if the seeding rate increased, the optimum seeding rate was determined as 120 seed $\mathrm{m}^{-2}$ because higher amounts did not showed a remarkable increase in seed yield. Among the seed vigor tests, electrical conductivity test gave accurate results for the prediction of field performance of safflower seed lots. It was concluded that $14 \mathrm{~cm}$ row spacing is suitable for both high yielding production and vigorous seeds, and seeding rate of 120 seed $\mathrm{m}^{-2}$ is suggested to enhance seed yield without a considerable changing in seed vigor performance of safflower.

\section{Acknowledgements}

The research was extracted from Master Thesis of first author I. OZASIK and financed by the Scientific Research Project Unit (BAP) of Eskisehir Osmangazi University with Project Number 2013/23A108.

\section{References}

Atak M, Kaya MD, Kaya G, Khawar KM. 2008. Dark green colored seeds increase the seed vigor and germination ability in dry green pea (Pisum sativum L.). Pak. J. Bot., 40(6): 23452354.

Baydar H, Ulger S. 1998. Correlations between changes in the amount of endogenous phytohormones and flowering in the safflower (Carthamus tinctorius L.). Turk. J. Biol., 22: 421425.

Bayramin S, Kaya MD. 2009. Advancement of safflower and rapeseed production of Turkey in recent years. Tarla Bitkileri Merkez Araştırma Enstitüsü Dergisi, 18: 43-47.

Coimbra RA, Martins CC, Tomaz CA, Nakagawa J. 2009. Vigor tests for selection of seed corn (sh2) seeds lot. Ciencia Rural, 39: 2402-2408.

Elfadl E, Reinbrecht C, Frick C, Claupein W. 2009. Optimization of nitrogen rate and seed density for safflower (Carthamus tinctorius L.) production under low-input farming conditions in temperate climate. Field Crops Res., 114(1): 2-13. 
Flagella Z, Rotunno T, Tarantino E, Caterina R, Caro A, Di Caterina R, Di Caterina A, De-Caro A. 2002. Changes in seed yield and oil fatty acid composition of high oleic sunflower (Helianthus annuus L.) hybrids in relation to the sowing date and the water regime. Eur. J. Agron., 17(3): 221-230.

Gonzalez JL, Schneiter AA, Riveland NR, Johnson BL. 1994. Response of hybrid and open-pollinated safflower to plant population. Agron. J., 86(6): 1070-1073.

Hampton JG, TeKrony DM. 1995. Handbook of vigour test

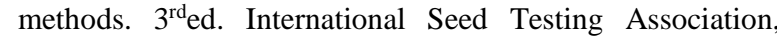
Zurich.

ISTA 2003. International Rules For Seed Testing. (2003 Ed). International Seed Testing Association, Bassersdorf, Switzerland.

Kaya MD. 2014. Conformity of vigor tests to determine the seed quality of safflower (Carthamus tinctorius L.) cultivars. Aust. J. Crop Sci., 8(3): 455-459.

Loeffler NL, Meier JL, Burris JS. 1985. Comparison of two cold test procedures for use in maize-drying studies. Seed Sci. Technol., 13(3): 653-658.

Mündel HH, Morrison RJ, Entz T, Blackshaw RE, Roth BT, Kiehn F, Vandenberg A. 1994. Row spacing and seeding rates to optimize safflower yield on the Canadian Prairies. Can. J. Plant Sci., 74: 319-321.
Reddy GKM, Dangi KS, Kumar SS, Reddy AV. 2003. Effect of moisture stress on seed yield and quality in sunflower (Helianthus annuus L.). J. Oilseed Res., 20: 282-283.

Riveland NR, French EW, Bradbury GT 1977. Proper seeding rate for safflower. North Dakota Agric. Exp. Sta. Reprint No. 909; Farm Res., 34(4): 19-20.

Umrani NK, Bhoi PG. 1984. Effect of plant density on growth and yield of safflower under two rainfall situations. Indian J. Agron., 29(3): 282-286.

Vieira RD, Paiva-Aguero JA, Perecin D, Bittencourt SRM. 1999. Correlation of electrical conductivity and other vigor tests with field emergence of soybean seedlings. Seed Sci. Technol., 27(1): 67-75.

Weiss EA. 2000. Oilseed Crops. ( $2^{\text {nd }}$ Ed) Blackwell Science Ltd. UK.

Zadeh KNA, Naseri R, Mirzaei A, Soleymanifard A. 2012. Effects of planting pattern on yield, its components, oil contain and some important agronomic traits of safflower (Carthamus tinctorius L.) in dry land conditions. Int. J. Agric. Crop Sci., 4(2): 86-91. 